\title{
26. CALCAREOUS NANNOFOSSILS: LEG 19 OF THE DEEP SEA DRILLING PROJECT
}

\author{
Thomas R. Worsley, University of Washington, Seattle, Washington
}

\section{INTRODUCTION}

Calcareous nannofossils are the minute $(1-20 \mu)$ skeletal remains of planktonic members of the golden brown algae. They are essentially tropical or subtropical organisms but cosmopolitan and high-latitude species are known (Edwards, 1968a, b; McIntyre, Be, and Roche, 1970; Worsley and Martini, 1970;). However, remains are not common in high-latitude sediments. Therefore, it is not surprising that the Neogene assemblages found in the North Pacific and Bering Sea have low population density and species diversity. Paleocene and Maestrichtian assemblages from the North Pacific are more diverse, suggesting more moderate global climate, and/or large translatitudinal plate motion.

In the Bering Sea, six sites were drilled (Figure 1) and the oldest sediments cored are Miocene. Most analyzed samples are completely devoid of calcareous nannofossils and little interpretation is offered here of the significance of the few fossiliferous samples, other than to note in the site reports where they occur. The reader is referred to the site reports and to the foraminifera chapter in this volume for detailed paleoclimatic interpretation.

In the North Pacific, five sites (Figure 1) were drilled, two of which contain more diversified nannofloras than any site in the Bering Sea. Meiji Guyot (Site 192) at the northwestern terminus of the Emperor seamount chain contains a somewhat impoverished Neogene assemblage underlain by progressively richer ones of Oligocene, Eocene, and Maestrichtian age. The Mesozoic-Cenozoic boundary was cored here, thereby demonstrating the complete absence of Paleocene strata at this site. The Gulf of Alaska (Site 183) is devoid of Neogene nannofossils and was apparently below the carbonate compensation depth (CCD) throughout its Neogene depositional history. Below, extremely sparse nannofloras occur in a thick turbidite sequence between a thin ( 1 to 20 meters) Oligocene nannofossil-rich chalk bed and a 1- to 2-meter-thick upper lower Eocene nannofossil-rich limestone bed.

The other North Pacific sites (Figure 1) contain no nannofossils.

\section{CALCAREOUS NANNOFOSSIL BIOSTRATIGRAPHY}

Biostratigraphy is ultimately based on accurately determining the relative abundance or absence-presence relationships of taxa in samples. If specimens are too rare in samples, it is not generally possible to accurately determine relative abundances or stratigraphic ranges. For this reason,

\footnotetext{
${ }^{1}$ Contribution No. 690 from the Department of Oceanography, University of Washington.
}

detailed biostratigraphic subdivision of the impoverished Neogene assemblages recovered in the Bering Sea and North Pacific is not attempted. Most biostratigraphic control for this part of the column is based on silicoflagellates and diatoms. The reader is referred to those chapters for biostratigraphy. Unfortunately, siliceous fossils are absent below the Neogene so that age determinations for this part of the column are entirely based on planktonic foraminifers and calcareous nannofossils for Meiji Guyot (Site 192) and nannofossils alone for the Gulf of Alaska (Site 183).

No new biostratigraphic subdivisions are proposed for the North Pacific Paleogene. Instead, samples have been assigned to Martini's (1971) standard zones where feasible or assigned to an epoch or part thereof where a zonal assignment could not be made. Tables 1 and 2 are the nannofossil range charts of the North Pacific. In these range charts, $A$ indicates more than 1 specimen per field of view; $C, 1 / 10$ to 1 specimen per field of view; $R$, less than $1 / 100$ specimen per field of view; and $X$, presence noted, abundance not determined. The field of view was at $640 \mathrm{X}$ magnification. Usually, as was done in this study, smear slides are used for age determinations. They frequently contain in excess of 30 specimens per field of view so that 20 minutes of observation at a rate of 5 fields of view per minute would total 100 fields or 3000 specimens. Unfortunately many of the samples studied here have far less than 1 specimen per field of view so that only a few specimens were found in 20 minutes of searching. Therefore, in the Paleogene portion of Site 183 where nannofossils are extremely scarce, with the exception of the two carbonate beds, and where no other fossil control is available, searching was continued long past twenty minutes and for as much as 4 to 5 hours for some critical samples. Even with these long searching times, the total number of specimens observed did not exceed a few hundred to a thousand, most of which were not age diagnostic. It is not improbable that still longer searching will reveal even more species for these samples.

\section{NANNOFOSSIL PALEOECOLOGY OF THE NORTH PACIFIC}

\section{Background}

Paleoecology, like biostratigraphy, is essentially dependent upon determining relative abundance or presenceabsence of taxa with samples. In biostratigraphy, the age of the sample is unknown and relative abundance or presenceabsence is assumed to have evolutionary and therefore age significance. The reverse is true in paleoecology where the age of a sample must be known before attaching environmental significance to relative abundance or presenceabsence of taxa. This is, at least in part, circular if the same fossil group is used for both age determination and 


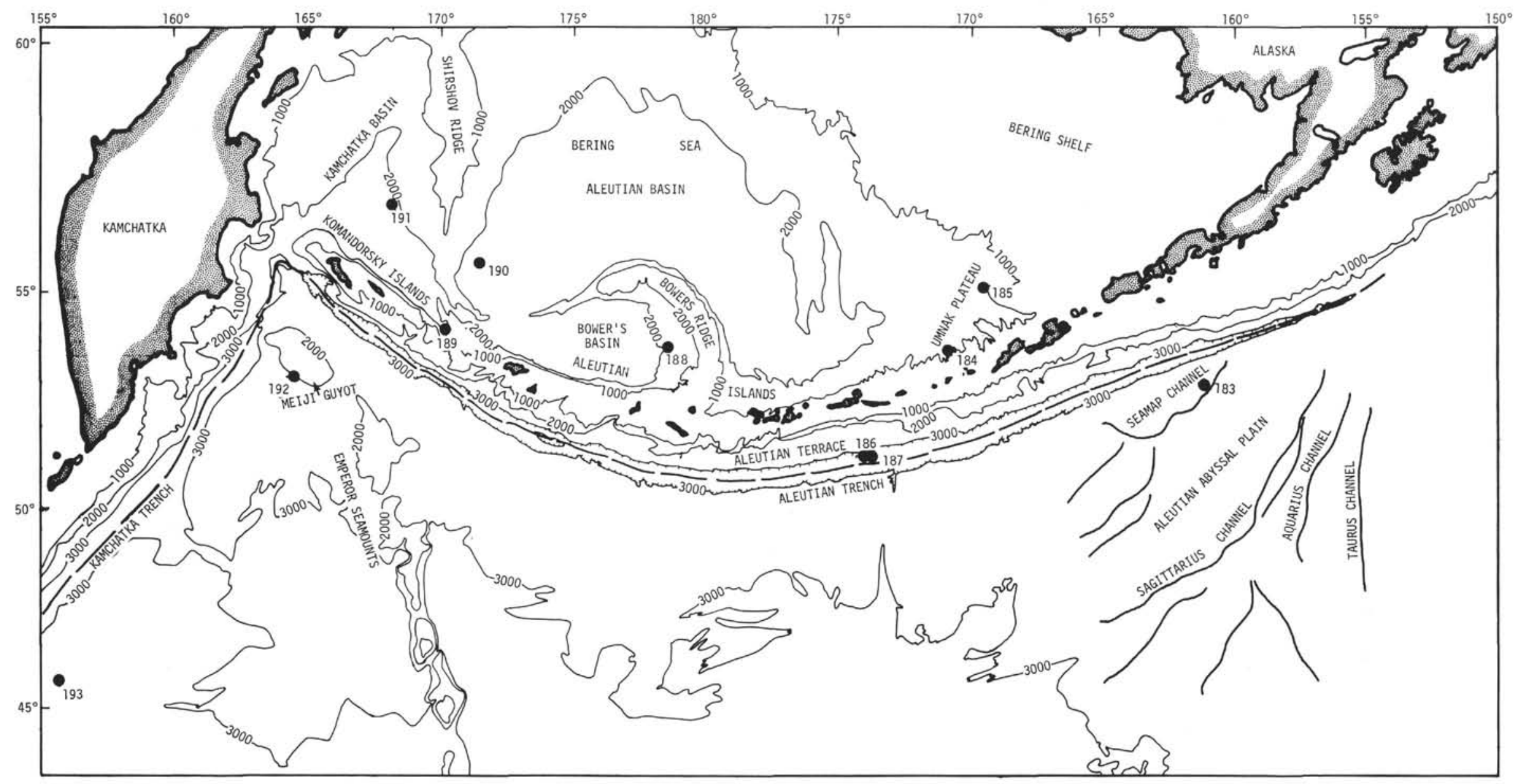

Figure 1. Base map, Leg 19, showing drill sites in the northern Pacific Ocean and Bering Sea. 
TABLE 1

Nannofossils, Leg 19

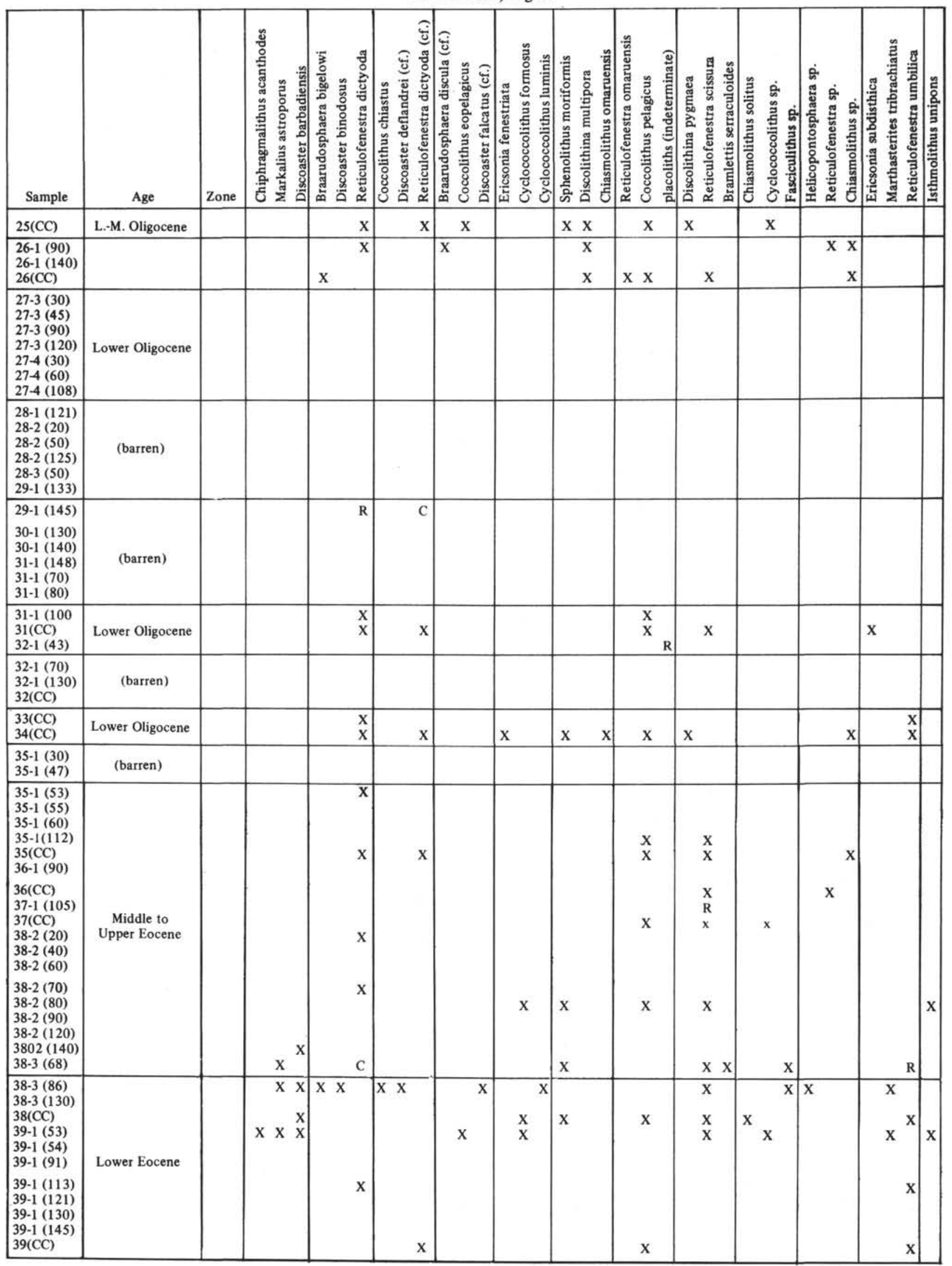


TABLE 2A

Nannofossils, Leg 19

\begin{tabular}{|c|c|c|c|c|c|c|c|c|c|c|c|c|c|c|}
\hline \multicolumn{3}{|c|}{ Hole 192} & \multirow{2}{*}{ 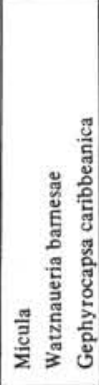 } & \multirow{2}{*}{ 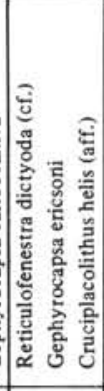 } & \multirow{2}{*}{ 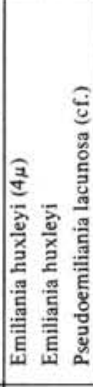 } & \multirow{2}{*}{ 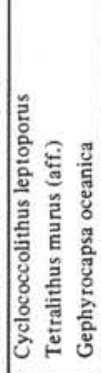 } & \multirow[t]{2}{*}{ 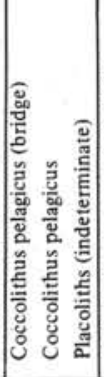 } & \multirow[t]{2}{*}{ 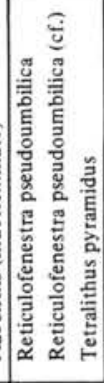 } & \multirow{2}{*}{ 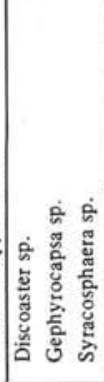 } & \multirow{2}{*}{ 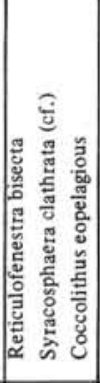 } & \multirow{2}{*}{ 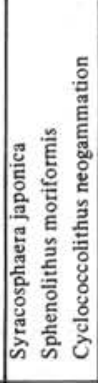 } & \multirow{2}{*}{ 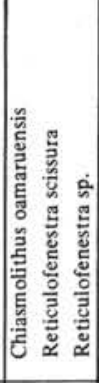 } & \multirow{2}{*}{ 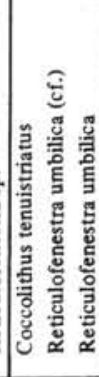 } & \multirow{2}{*}{ 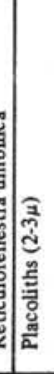 } \\
\hline Sample & Age & Zone & & & & & & & & & & & & \\
\hline $\begin{array}{l}1-1(80) \\
1(\mathrm{CC}) \\
2-1(114) \\
2-2(80)\end{array}$ & $\begin{array}{c}\text { Upper } \\
\text { Pleistocene }\end{array}$ & $\mathrm{NN} 21$ & & $\begin{array}{l}R \\
X \\
R\end{array}$ & \begin{tabular}{r|r} 
C & $R$ \\
& $x$ \\
$\times$ & $R$ \\
\end{tabular} & \begin{tabular}{|ll}
$\mathrm{X}$ & $\mathrm{R}$ \\
$\mathrm{R}$ & $\mathrm{R}$ \\
\end{tabular} & \begin{tabular}{|l|l}
$\mathrm{C}$ & $\mathrm{A}$ \\
$\mathrm{X}$ & $\mathrm{X}$ \\
& $\mathrm{R}$ \\
& $\mathrm{C}$
\end{tabular} & $\mathbf{R}$ & $\mathrm{x}$ & & & & & \\
\hline $\begin{array}{l}2-3(80) \\
2-4(80) \\
2(\mathrm{CC}) \\
3-1(79) \\
3-2(70) \\
3-3(79)\end{array}$ & (barren) & & & & & & & & & & & & & \\
\hline $\begin{array}{l}3-4(75) \\
3(\mathrm{CC}) \\
4-1(80) \\
4-2(80) \\
4-3(80) \\
4-4(80) \\
4-5(80) \\
4-6(80) \\
4(\mathrm{CC}) \\
5-1(80) \\
5-1(84) \\
5-2(80) \\
5-3(80) \\
\end{array}$ & $\begin{array}{c}\text { Middle } \\
\text { Pleistocene }\end{array}$ & $\begin{array}{c}\text { NN20 } \\
(?) \\
\text { NN19 }\end{array}$ & $x \quad x$ & 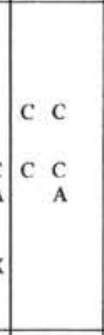 & $\begin{array}{l}\mathrm{R}^{\mathrm{C}} \\
\mathrm{x}\end{array}$ & \begin{tabular}{|lll}
$R$ & $C$ \\
& & \\
& & \\
& $C$ & $C$
\end{tabular} & $\begin{array}{lll}\text { c } & c \\
\text { C } & c & \\
x & x & x \\
& & \\
& c & \\
C & c\end{array}$ & $\begin{array}{l}\mathrm{R} \\
\mathrm{C}\end{array}$ & & & & & & \\
\hline $\begin{array}{l}-4(80) \\
5-5(80) \\
5-6(140)\end{array}$ & (barren) & & & & & & & & & & & & & \\
\hline $5(\mathrm{CC})$ & L. Pleist. & & & & & & $\mathrm{x}$ & & & $x$ & & & & \\
\hline $\begin{array}{l}6-1(120) \\
6-2(80) \\
6(C C) \\
7-1(100) \\
7-2(40) \\
7-3(80) \\
7-4(80) \\
\end{array}$ & (barren) & & & & & & & & & & & & & \\
\hline $7(\mathrm{CC})$ & U. Plio. & & & & $x$ & $x$ & & $\mathrm{X}$ & $\mathrm{X}$ & & & & & \\
\hline $\begin{array}{l}8-1(125) \\
8-2(94) \\
8-3(120) \\
8-4(68) \\
8-5(80) \\
8-6(80) \\
8(C C) \\
9-1(130) \\
9-2(80) \\
9-3(80) \\
9-5(80) \\
9-6(80) \\
9(C C) \\
10-1(140) \\
10-2(80) \\
10-3(80) \\
\end{array}$ & (barren) & & & & & & $\mathrm{x}$ & & & & & & & \\
\hline $\begin{array}{l}10-4(80) \\
10(\mathrm{CC}) \\
11-1 \text { (top) } \\
11-2(80) \\
11(\mathrm{CC}) \\
12-1 \text { (top) } \\
12-2(80) \\
12-3(80) \\
12-4(80) \\
12(\mathrm{CC}) \\
13-2(80) \\
13-3(80) \\
13-4(80) \\
13-5(80) \\
13(\mathrm{CC}) \\
14-1(110) \\
14-2(80) \\
14-3(80) \\
14(\mathrm{CC}) \\
\end{array}$ & $\begin{array}{l}\text { Lower } \\
\text { Pliocene }\end{array}$ & & $\begin{array}{l}\mathbf{R} \\
\mathbf{R}\end{array}$ & $\begin{array}{ll}C \\
X \\
x & R \\
x \\
C \\
\\
\\
R & R \\
X & \end{array}$ & R & $\mathrm{x}$ & 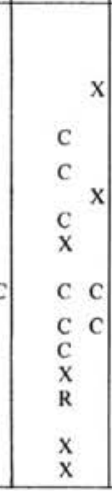 & 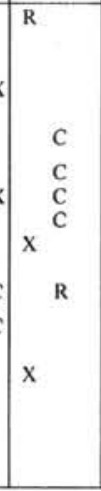 & $\begin{array}{l}X \\
R \\
X \\
X \\
\\
R \\
X \\
X \\
C \\
\end{array}$ & & & & & \\
\hline
\end{tabular}


TABLE 2A - Continued

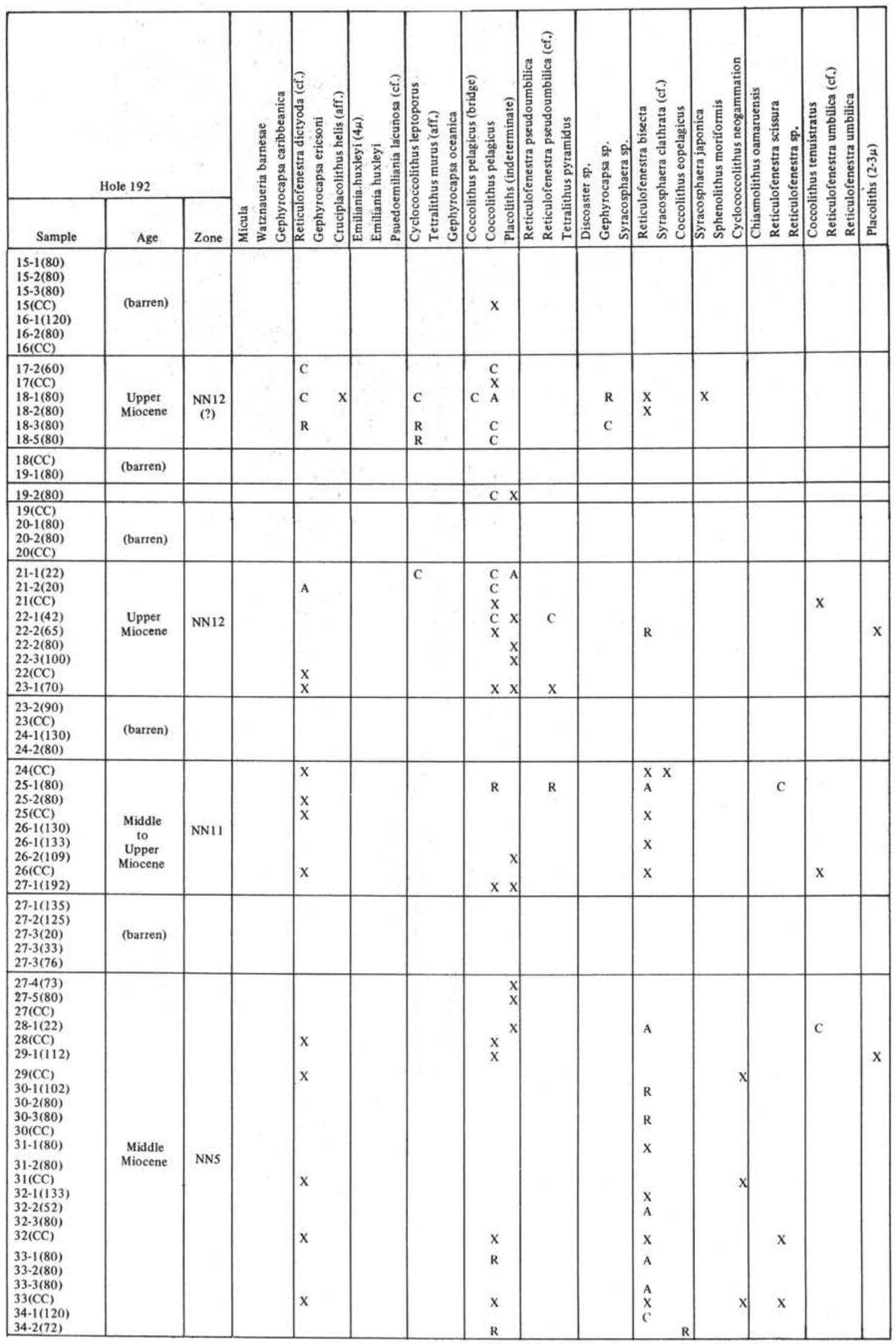




\begin{tabular}{|c|c|c|c|c|c|c|c|c|c|c|c|c|c|c|}
\hline \multicolumn{3}{|c|}{ Hole 192} & \multirow{2}{*}{ 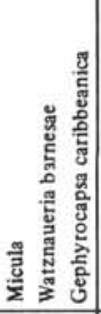 } & \multirow{2}{*}{ 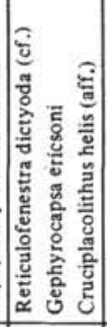 } & \multirow{2}{*}{ 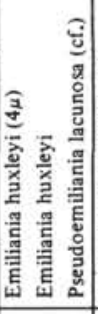 } & \multirow{2}{*}{ 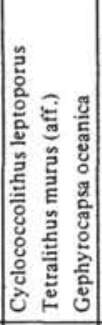 } & \multirow{2}{*}{ 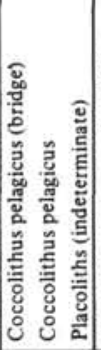 } & \multirow{2}{*}{ 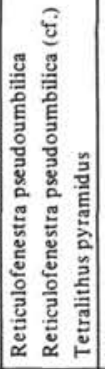 } & \multirow{2}{*}{ 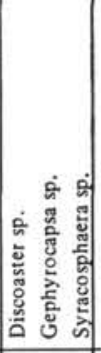 } & \multirow{2}{*}{ 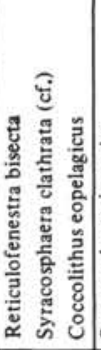 } & \multirow{2}{*}{ 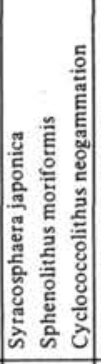 } & \multirow{2}{*}{ 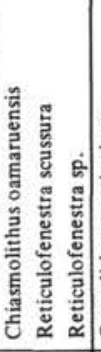 } & \multirow{2}{*}{ 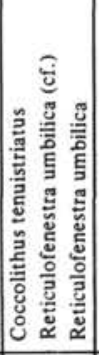 } & \multirow{2}{*}{ 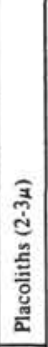 } \\
\hline Sample & Age & Zone & & & & & & & & & & & & \\
\hline $\begin{array}{l}34-2(90) \\
34-3(80) \\
34-4(77) \\
34-5(81) \\
34-6(92) \\
34(C C) \\
35-1(85) \\
35(C C) \\
36(C C)\end{array}$ & $\begin{array}{l}\text { Lower } \\
\text { Pliocene }\end{array}$ & NN5 & & $x$ & & & $x$ & & & $\begin{array}{l}x \\
x \\
x \\
A \\
x\end{array}$ & $x$ & \begin{tabular}{ll}
\multicolumn{2}{c}{$x$} \\
$c^{2}$ & \\
$x$ &
\end{tabular} & & $x$ \\
\hline
\end{tabular}

paleoecologic reconstruction. Therefore, without independent age control, paleoecological-biostratigraphic studies always contain an inherently large degree of subjectivity. This is especially true of the inferences about the Paleogene environment of the Gulf of Alaska (Site 183) where nannofossils are the sole fossil group recovered. The situation is better for Meiji Seamount where planktonic foraminifers are present also. For a detailed summary of the consequences of the paleoecological interpretations offered below, the reader is referred to the synthesis chapter in this volume.

Table 3 summarizes many of the significant physical, ecological, and taxonomic characteristics of four localities on the northern and eastern perimeter of the North Pacific (denoted by asterisks on Figure 1). As the paleontologic data of the table are mainly dependent on the absence or presence of taxa in the specified localities, it would be well to review the factors controlling nannofossil distribution in coeval deposits before interpreting the data. They are paleodepth of water, past levels of the carbonate compensation depth, past climate, and paleospastic position.

Information on the paleodepth of deposition for many oceanic (but not shelf) cores can be obtained if one assumes that all oceanic crust forms on ridge crests, subsequently founders as spreading proceeds, and is finally subducted into a trench. Sclater et al. (1971) have found a relationship between age of the oceanic crust and its depth below sea level. Most ridge crests average 2 to $3 \mathrm{~km}$ below sea level and ultimately founder to perhaps $5 \mathrm{~km}$ prior to subduction. When graphed, this relationship closely approximates a catenary curve of age versus depth. In this study, corrections have been applied to obtain paleodepths for the two oceanic sites. Only paleontologic criteria are available for determining paleodepth of the shelf sites but these were certainly much shallower than the oceanic ones.

Besides the depth to the sea floor, the carbonate compensation depth has also changed through time by as much as $1 \mathrm{~km}$ for the Atlantic (Hay, 1970; Ramsay, 1973). This means that even though "Sclater curves" have been applied to an oceanic locality, one cannot be sure of knowing the relation of the sediment-water interface to the carbonate compensation depth without additional information. Age versus CCD curves are available for the Atlantic (Ramsay, 1973), but not yet for the Pacific so that much of the information presented below with respect to this topic is subjective.

Besides being dependent on water depth and the CCD, the quantity of biogenic calcite in a sediment is also a function of surface water temperature at time of deposition. The colder the climate, the lower the specimen density and species diversity in surface waters and therefore in sediments. Climate at a site can change by either having climatic belts migrate across the site or having the site migrate across climatic belts. That both occur is demonstrated by the record of the ice ages for the first case or in the hypotheses of sea floor spreading and polar wandering for the second.

Meiji Guyot and the Gulf of Alaska have probably been strongly affected by all four of these processes. The question is, which dominated when? If a unique solution is attainable, information about paleoclimate, paleo-ocean chemistry, sea floor spreading, and absolute plate motion can be obtained. For this reason, interpretation is attempted regardless of the ambiguity in the small amount of data available in the hope it will stimulate further research into this complex and fascinating problem.

\section{CONCLUSIONS}

Available evidence seems to favor cool- to cold-water deposition for the Paleogene sediments of Meiji Guyot and the Gulf of Alaska. However, warm-water conditions are suggested for the Maestrichtian of Meiji Seamount. Species diversity (Table 3 ) in the North Pacific is only a fraction of that in Southern California. Only four species of Discoaster occur in the North Pacific compared to twentyone in coeval deposits in Southern California. If climates were similar for both regions at that time, discoasters should have been equally well represented in all four sites because they are known to occur abundantly in both shelf 
TABLE 2B

Nannofossils, Leg 19

\begin{tabular}{|c|c|c|c|c|c|c|c|c|c|c|c|c|c|c|c|c|}
\hline \multicolumn{3}{|c|}{ Hole $192 \mathrm{~A}$} & \multirow{2}{*}{ 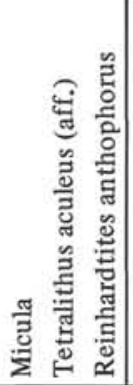 } & \multirow{2}{*}{ 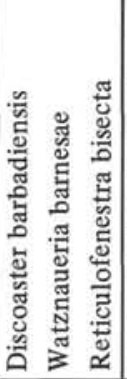 } & \multirow{2}{*}{ 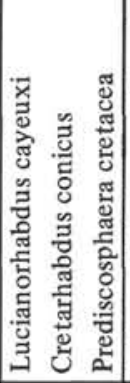 } & \multirow{2}{*}{ 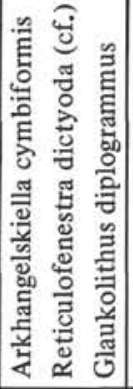 } & \multirow{2}{*}{ 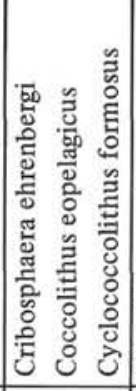 } & \multirow{2}{*}{ 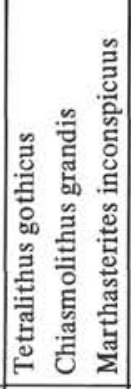 } & \multirow{2}{*}{ 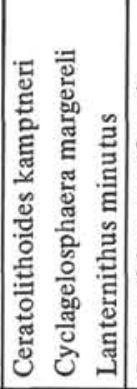 } & \multirow{2}{*}{ 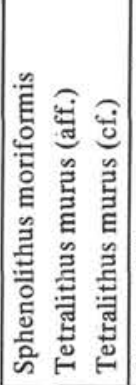 } & \multirow{2}{*}{ 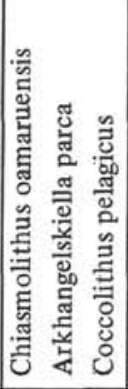 } & \multirow{2}{*}{ 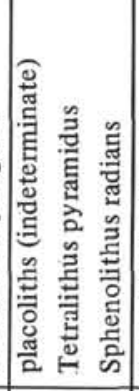 } & \multirow{2}{*}{ 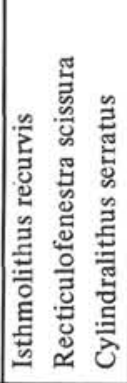 } & \multirow{2}{*}{ 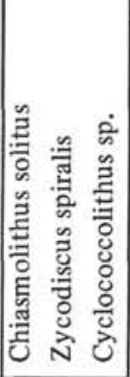 } & \multirow{2}{*}{ 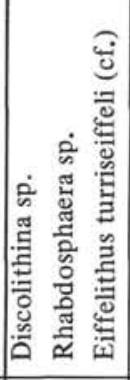 } & \multirow{2}{*}{ 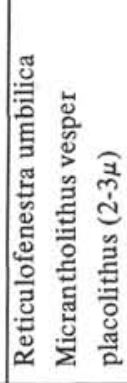 } \\
\hline Sample & Age & Zone & & & & & & & & & & & & & & \\
\hline $\begin{array}{l}1-1(105) \\
1-2(77) \\
1-3(38) \\
1-4(65) \\
1-5(80) \\
1-6(53) \\
1-6(113) \\
1(C C) \\
\end{array}$ & $\begin{array}{l}\text { Upper } \\
\text { Upper } \\
\text { Eocene- } \\
\text { Lower } \\
\text { Oligocene }\end{array}$ & NP19-22 & & \begin{tabular}{l|}
$\mathrm{A}$ \\
$\mathrm{A}$ \\
$\mathrm{X}$ \\
$\mathrm{A}$ \\
$\mathrm{A}$ \\
$\mathrm{X}$ \\
$\mathrm{X}$
\end{tabular} & & & $\mathrm{X}$ & & $\mathrm{R}$ & $\mathrm{X}$ & R & $\mathrm{X}$ & $\mathrm{X}$ & & $\mathrm{X} X$ & $\begin{array}{l}\mathrm{C} \\
\mathrm{X} \\
\mathrm{C} \\
\mathrm{R} \\
\mathrm{X} \\
\mathrm{X}\end{array}$ \\
\hline $\begin{array}{l}2-1(74) \\
2-2(54) \\
2-2(124) \\
2-3(62) \\
2-4(94) \\
2-5(103) \\
2-6(125) \\
2(C C) \\
3-2(89) \\
3-3(89) \\
3(C C)\end{array}$ & $\begin{array}{l}\text { Lower } \\
\text { Upper } \\
\text { Eocene }\end{array}$ & NP17-18 & $\mathrm{X}$ & \begin{tabular}{l|}
$\mathrm{X}$ \\
$\mathrm{X}$ \\
$\mathrm{X}$ \\
$\mathrm{X}$ \\
$\mathrm{X}$ \\
$\mathrm{X}$
\end{tabular} & & $\mathrm{X}$ & & & & $x^{X}$ & & & $\mathrm{X}$ & $\mathrm{X}$ & & $\begin{array}{l}\mathrm{X} \\
\mathrm{X}\end{array}$ \\
\hline $\begin{array}{l}\text { 4-1(top) } \\
4-2(75) \\
4-2(95)\end{array}$ & $\begin{array}{l}\text { Upper } \\
\text { Middle } \\
\text { Eocene }\end{array}$ & NP15-16 & & \begin{tabular}{l|l}
$\mathrm{C}$ \\
$\mathrm{C}$
\end{tabular} & & & $\mathrm{X} \quad \mathrm{X}$ & $\mathrm{X}$ & & & $\begin{array}{ll} & \mathrm{X} \\
\mathrm{R} & \mathrm{C} \\
\mathrm{R} & \mathrm{C}\end{array}$ & $\mathrm{x}$ & C & $\mathrm{X}$ & & $\begin{array}{lll}\mathrm{X} & \mathrm{X} & \\
\mathrm{C} & \mathrm{R} & \mathrm{C} \\
\mathrm{C} & & \mathrm{C}\end{array}$ \\
\hline $\begin{array}{l}\text { 4-4(top) } \\
4-4(72) \\
4(C C)[\text { top] }\end{array}$ & $\begin{array}{l}\text { Lower } \\
\text { Eocene }\end{array}$ & NP12-14 & $\mathrm{R}$ & \begin{tabular}{l|}
$\mathrm{A}$ \\
$\mathrm{X}$
\end{tabular} & & & $\mathrm{C}$ & $\mathrm{X}$ & & $\mathrm{X} \quad \mathrm{x}$ & $\mathrm{x}$ & $x$ & $\mathrm{C}$ & $X$ & & $X$ \\
\hline $\begin{array}{l}4(C C)[\text { bot }] \\
5-0 \\
5-0 \\
5-1(70) \\
5-1(75) \\
5-1(85) \\
\end{array}$ & $\begin{array}{c}\text { Middle } \\
\text { Maestrichtian }\end{array}$ & & $\begin{array}{l}\mathrm{X} \\
\mathrm{A} \\
\mathrm{X} \\
\mathrm{A} \\
\mathrm{A}\end{array}$ & $\begin{array}{l}\mathrm{X} \\
\mathrm{A} \\
\\
\mathrm{A} \\
\mathrm{A}\end{array}$ & & $\mathrm{X}_{\mathrm{R}}$ & & $\begin{array}{l}\mathrm{C} \\
\mathrm{X} \\
\mathrm{C} \\
\mathrm{C}\end{array}$ & $\begin{array}{ll}R^{2} & \\
& \\
R & \\
R & \end{array}$ & $\begin{array}{ll}X & X \\
A \\
X \\
A \\
A\end{array}$ & $\begin{array}{l}\mathrm{X} \\
\mathrm{R} \\
\\
\mathrm{R} \\
\mathrm{R}\end{array}$ & $\mathrm{X}$ & $\mathrm{X}$ & $\begin{array}{l}\mathrm{R} \\
\mathrm{R} \\
\mathrm{R}\end{array}$ & & \\
\hline $\begin{array}{l}5-3(55) \\
5(\mathrm{CC})\end{array}$ & $\begin{array}{c}\text { Lower } \\
\text { Maestrichtian }\end{array}$ & & $\mathrm{X}$ & $\mathrm{X}$ & $\begin{array}{lll}X & X & x\end{array} \mid$ & $\mathrm{x}$ & $\mathrm{X}$ & & $\mathrm{X}$ & $\mathrm{x}$ & $\mathrm{X}$ & $\mathrm{X}$ & $\mathrm{x}$ & $\mathrm{X}$ & $\mathrm{x}$ & \\
\hline
\end{tabular}


TABLE 3

Selected Biostratigraphic Data

\begin{tabular}{lcccc}
\hline & Site 192 & Site 183 & Washington & California ${ }^{\mathrm{b}}$ \\
\hline Location & $53^{\circ} \mathrm{N}, 164^{\circ} \mathrm{E}$ & $52^{\circ} \mathrm{N}, 161^{\circ} \mathrm{W}$ & $48^{\circ} \mathrm{N}, 124^{\circ} \mathrm{W}$ & $37^{\circ} \mathrm{N}, 120^{\circ} \mathrm{W}$ \\
Water Depth (m) & 3024 & 4718 & subaerial & subaerial \\
Deposition Type & pelagic & pelagic and dis- & shelf & shelf \\
& & placed shelf & & \\
Age Control & & & & \\
Foraminifera & yes & no & yes & yes \\
Radiolaria & no & no & no & partial \\
Diatoms & no & no & no & partial \\
Silicoflagellates & no & yes & no & partial \\
Magnetic & no & no & yes & yes \\
Isotopic & $12-15$ & 23 & yes & yes \\
Nannofossil Species & 1 & 4 & $\sim 50$ & $\sim 100$ \\
Discoaster Spp. & 2 & 1 & 10 & 21 \\
Sphenolith Spp. & 1 & 2 & 3 & 3 \\
Pontosphaerid Spp. & - & $1(?)$ & 7 & 15 \\
Helicopontosphaerid Spp. & & & 3 & 3 \\
Cool-Water Species & yes & no & yes & no \\
Isthmolithus recuvis & yes & yes & yes & $(?)$ \\
Chiasmolithus oamaruensis & yes & no & yes & $(?)$ \\
Lanternithis minutus & cool-cold & cold & cold & warm \\
Water Paleotemperature & $<3000$ & $\sim 3000$ & bathyl(?) & shallow \\
Paleodepth (m) & & & & bathyl(?) \\
& NP12-14 & NP12-13 & NP14-16 & NP12-15 \\
Zone Range & & & & \\
\hline & & & &
\end{tabular}

aWorsley and Crecelius, 1972.

$\mathrm{b}_{\text {Bramlette and Sullivan, } 1961 .}$

cSite survey.

d Tabor, 1972.

Evernden and Evernden, 1970.

and deep ocean sediments and also because they are known to have the deepest compensation depth of all Paleogene nannofossils. A latitudinal trend similar to that of the discoasters is observed for sphenoliths, helicopontosphaerids, and pontosphaerids, all of which, like discoasters, are thermophilic. However, unlike discoasters, these three groups have relatively shallow compensation depths and prefer shelf conditions (Edwards, 1968; Bukry 1970). Therefore, proximity to shore and water depth, as well as paleotemperature, probably contribute to their observed distribution pattern in the North Pacific margin.

Further evidence for upper Eocene cool-water deposition lies in the occurrences of Isthmolithus recurvis, Lanthernithus minutus, and Chiasmolithus oamaruensis without other upper Eocene "guide fossils" (Edwards, 1968; Worsley and Jorgens, in press). The nonoccurrence of middle Eocene chert in the North Pacific sites as opposed to ubiquitous occurrences at lower latitudes suggests deposition in the barren central water mass of the North Pacific during Eocene time. This could also account for the puzzling absence of siliceous microfossils at these sites despite their widespread occurrence and abundance at this time.

Maestrichtian assemblages recovered from Meiji Guyot have a generally tropical aspect. Members of the Tetralithus complex similar to the tropical $T$. murus occur, but Nephrolithus, a coeval genus having cooler water preference, is absent. The occurrence of the tropical
Ceratolithoides kamptneri and the extinction of Lucianorhabdus cayeuxi below that of Cylandralithus serratus are supporting evidence for generally warm surface waters. However, the absence of siliceous microfossils suggests deposition north of the equatorial belt of high productivity.

\section{ACKNOWLEDGMENTS}

I wish to thank Connie Aitkin, Maurice Jorgens, and Scott Ralston for their assistance in preparing the manuscript. This research was in part supported by National Science Foundation Science Development Grant GU-2655 to the University of Washington.

\section{REFERENCES}

Bukry, D., 1970. Coccolith age determinations Leg 2, Deep Sea Drilling Project. In Peterson, M.N.A., Edgar, N. T. et al., 1970. Initial Reports of the Deep Sea Drilling Project, Volume II. Washington (U.S. Government Printing Office). 349.

Bramlette, M. N. and Sullivan, F. R., 1961. Coccolithophorids and related nannoplankton of the Early Tertiary in California. Micropaleontology. 7 (2), 129.

Edwards, A. R., 1968a. The calcareous nannoplankton evidence for New Zealand Tertiary marine climate. Tuatara. $16(1), 26$.

1968b. Marine climates in the Oamaru District during Late Kaiatan to Early Whaingaroan time. Tuatara. $16(1), 75$. 
Evernden, J. F. and Evernden, R.K.S., 1970. Radiometric dating and paleontologic zonation. Geol. Soc. Am. Spec. Paper 124. 71.

Hay, W. W., 1970. Calcium carbonate compensation. In: Bader, R. G., Gerard, R. D. et al., 1970. Initial Reports of the Deep Sea Drilling Project, Volume IV. Washington (U.S. Government Printing Office). 659.

Loeblich, A. R. and Tappan, H., 1966. Annotated index and bibliography of the calcareous nannoplankton. Phy cologia. 5, 81 . 1968. Annotated index and bibliography of the calcareous nannoplankton II. J. Paleontol. 42, 584. 1969. Annotated index and bibliography of the calcareous nannoplankton III. J. Paleontol. 43, 568 . 1970a. Annotated index and bibliography of the calcareous nannoplankton IV. J. Paleontol. 44, 558 . $1970 \mathrm{~b}$. Annotated index and bibliography of the calcareous nannoplankton V. Phycologia. 9, 157.

Martini, E., 1971. Standard Tertiary and Quaternary calcareous nannoplankton zonation. In A. Farinacci (Ed.). II Planktonic Conference Proc. 2. 739.

McIntyre, A., Be, A.W.H., and Roche, M. B., 1970. Modern Pacific coccolithophorida: a paleontological thermometer. Trans. New York Acad. Sci., Ser. II. 32 (6), 720.

Ramsay, A.T.S., 1973. History of Cenozoic carbonate compensation depth changes in the Atlantic Ocean. In: Hay, W. W. (Ed.). S.E.P.M. Symposium on the history of the ocean basins.

Roth, P. H., 1970. Oligocene calcareous nannoplankton biostratigraphy. Ecl. Geol. Helv. 63 (3), 799

Sclater, J. G., Anderson, R. W., and Bell, M. L., 1971. Elevation of ridges and evolution of the Central Eastern Pacific. J. Geophys. Res. 76, 7888.

Tabor, Rowland W., 1972. Age of the Olympic metamorphism, Washington: $\mathrm{K}-\mathrm{Ar}$ dating of low-grade metamorphic rocks. Geol. Soc. Am. 83, 1805.

Worsley, T. R., and Crecelius, E., 1972. Paleogene calcareous nannofossils from the Olympic Peninsula, Washington. Geol. Soc. Am. 83, 2859.

Worsley, T. R., and Jorgens, M. L., in press. Oligocene calcareous nannofossil provinces. In: Ross, C. A. (Ed.). S.E.P.M. Symposium on Paleoprovinciality, Denver, 1971.

Worsley, T. R., and Martini, E., 1970. Late Maestrichtian nannoplankton provinces. Nature. 225, 1242.

\section{APPENDIX \\ TAXONOMIC NOTES}

The generally impoverished nannofloral assemblages from the North Pacific and Bering Sea differ slightly from lower latitude ones on the subspecific level. However, because their areal and stratigraphic distribution is so imperfectly known at this time and because only light microscopy has been used in identifying them, no new taxa have been erected and these variants have been included within established species. The following paragraphs describe fifteen forms which either differ slightly from original descriptions or exhibit wider morphologic variation than previously noted. All other species recorded in the range charts conform closely to previous descriptions. Reference to illustrations and synonomy of the taxa mentioned here may be found by consulting Loeblich and Tappan $(1966,1968,1969,1970 a, b)$.

\section{Emiliania huxleyi}

A large size range is noted for specimens assigned to this species, with many approaching $4 \mu$. The large specimens appear to be high-latitude variants. A differentiation of ranges among the sizes proved unfeasible using light microscopy.

\section{Coccolithus pelagicus}

Included is Ericsonia muiri of the middle and lower Cenozoic. Specimens possessing a bridge across the central area seem restricted to the Pleistocene.

\section{Gephyrocapsa oceanica}

Occurs rarely, probably in part because solution differentially attacks the bridge, rendering specific identification by light microscopy difficult to impossible.

\section{Reticulofenestra aff. dictyocha}

Includes generalized placoliths of many sizes having swasticoidal interference crosses which break into infinity signs upon rotation of the stage. This catchall probably includes several distinct species which are not easily separated in the light microscope. This type of placolith is the dominant nannofossil of the Bering Sea Miocene.

\section{Cruciplacolithus aff. neohelis}

This form coincides fairly closely with McIntyre's description of $C$. neohelis, but may be a variant of the bridge-bearing form of Coccolithus pelagicus. The central area is infilled with calcite and appears to be a cross aligned with the axes of the elliptical placolith.

\section{Gephyrocapsa ericsoni}

Identification of this small (2-3 micron) species is not certain in the light microscope. Very small Gephyrocapsa specimens are referred to it.

\section{Reticulofenestra cf. pseudoumbilica}

These specimens resemble $R$. pseudoumbilica except for their small (4-5 micron) size. They occur as low as the upper Miocene.

\section{"Cyclococcolithus leptoporus"}

Refers to all species within the "Cyclococcolithus" complex having a weak polarization figure and occurring in Miocene and younger sediments.

\section{Pseudoemiliania cf. lacunosa}

Refers to small species (about 4-5 microns) resembling this distinctive species. It is difficult to differentiate $P$. cf. lacunosa from the larger specimens of Emiliania huxleyi.

\section{Geophyrocapsa caribbeanica}

Refers to specimens within the Gephyrocapsa complex having crossbars more nearly aligned with the major axis of the elliptical placolith. They are thought to be the cold water form of $G$. oceanica.

\section{Tetralithus aff. murus}

Includes concave-convex tetraliths strongly resembling $T$. murus, but not having ray-tips which curve sharply clockwise when the convex side faces the observer. It is not certain whether they are true specimens of $T$. murus whose ray-tip curvature has been selectively removed by solution or if they are the evolutionary forerunners of $T$. murus. In any event, such forms seem to range throughout most of the Maestrichtian in many parts of the ocean, rather than being restricted to its upper part.

\section{Reticulofenestra cf. umbilica}

Refers to large placoliths which, like $R$. umbilica, have very large open central areas with respect to their diameters, but have an interference figure different from that of $R$. umbilica. They may be partially dissolved species of $R$. bisecta.

\section{R. bisecta}

Includes specimens larger than about $8 \mu$ conforming to the definition of Roth (1970). R. bisecta ranges from the Eocene to the base of the Pliocene in the North Pacific and Bering Sea, but becomes extinct near the base of the Miocene in lower latitudes. 
Smaller specimens somewhat resembling it are referred to $R$. dictyocha. Those smaller specimens exactly resembling it are referred to $R$. scissura = Ericsonia ovalis .

Tetralithus aff. aculeus

Refers to specimens intermediate between Ceratolithoides kamptneri and T. aculeus.
Tetralithus cf. murus

Includes quadrate forms resembling $T$. murus, but which appear not to be concave-convex.

"Cyclococcolithus neogammation"

Refers to all cyclococcoliths above the Oligocene having a strong polarization cross and small central pore. 